\title{
Evaluation of Hydro-Oceanographic Specialization Education Program in the Sea Naval Education- Oceanography Education Center
}

\author{
Harris Djoko Nugroho ${ }^{1, *}$ Muchlis R. Luddin², Maruf Akbar ${ }^{3}$ \\ ${ }^{1}$ Universitas Negeri Jakarta \\ ${ }^{2}$ Universitas Negeri Jakarta \\ ${ }^{3}$ Universitas Negeri Jakarta \\ *Corresponding author.Email: Harrisdjokonugroho@gmail.com
}

\begin{abstract}
This study aimed to evaluate the Hydro-Oceanographic Officer Specialization in Education Program at the Indonesian Navy's Hydro-Oceanographic Education Center. The method used was the evaluation study method with Kirkpatrick's model. The results of the study showed; (1) Reaction, DikspespaHidros program as a DikbangspesHidros program that refers to the International Hydrographic Organization (IHO) Curriculum has been recognized as "B" Category Hydrographic Surveyor Education even though it does not yet have educators from abroad, (2). Learning, there were some aspects of the assessment including the improvement of knowledge, skills and attitudes which all have good value, (3). Behavior, divided into two parts, namely work ability and alumni have work motivation so that they are able to apply knowledge well into work, physical abilities applied in carrying out tasks and emotional abilities show good work attitudes, and (4) result, alumni have satisfactory performance such as aspects of the quality of work, quantity of work, cooperation and work involvement are all classified as good. DikspespaHidros graduates generally can directly participate in Operation DikspespaHidros while alumni from non-hydros (Armada, Lantamal and Lanal) still need assistance in working.
\end{abstract}

Keywords: Evaluation Program, Specialization, Hydro Oceanography.

\section{INTRODUCTION}

Flanked by two continents (Asia-Australia) and two oceans (Pacific Ocean-Indian Ocean), it means that Indonesian geographical location is very strategic place which plays en essential role. According to the Navy's in reference [1] Indonesia has used as Sea Lines of Communications (SLOCs) and Sea Lines of Oil Trade (SLOT). Many nations, including the Indonesian people, depend on these two crucial shipping lanes for survival. As the result, assurances of shipping safety and protection in Indonesian waters are a source of concern and interest around the world.

The demand for security guarantees at SLOC and SLOT shows the dependence of many nations on the right and freedom of navigation. It means that there is a flow of ships that sail to go and come to transport raw materials and materials into ships that sail smoothly and uninterrupted and guarantee the continuity of production activities and distribution in the chain of economic processes in Indonesia. Therefore, changing the orientation of Indonesia's national development towards the maritime approach becomes an important and urgent matter. In the future, the sea area can be managed professionally and proportionally, in which it is always directed towards the basic interests of the Indonesian people at sea.

The Indonesian government realizes that a great transformation is taking place in the 21st Century, the dynamics of the strategic environment that are developing and changing the direction of Indonesia's development management policies which have tended to be land-oriented now oriented to the maritime. Therefore, President Joko Widodo explained Indonesia's vision to be a world maritime axis country at the East Asia Summit in Myanmar on November 13, 2014. It is a very strategic concept and vision opened opportunities for Indonesia to 
build regional and international cooperation in the marine sector for the prosperity of the Indonesian people.

Basically, the changing in development policies that are oriented to maritime, strategic environmental changes for the Indonesian Armed Forces (TNI) are also the driving force of the TNI to take various steps to change tasks, namely, the separation of the main tasks of the TNI through Military Operations for War (OMP) and Military Operations Other than War ( OMSP) as well as the implementation of military operations other than war which must be based on state policies and political decisions in accordance with paragraph 3, Law Number 34 concerning the Indonesian National Army.

Pushidrosal's main duty is to plan the landscape and weather for OMP tasks and play an active role in supporting CSOs, with tasks related to hydrography and oceanography being to conduct surveys and mapping in order to establish boundaries in the border zone, assist in the recovery from natural disasters, and assist in the search and rescue of aircraft. It is a line with Hydrographic and Oceanographic Center of the Indonesian National Armed Forces (Pushidrosal), previously known as the Hydrographic-Oceanographic Service of the Indonesian National Army Navy (Dishidrosal). Based on Presidential Regulation (Perpres) no. 62 of 2016 concerning changes to Presidential Regulation number 10 of 2010 that concern about the organizational structure of the Indonesian Armed Forces, stated that Pushidrosal is a forum for fostering the Navy which is located directly under Kasal.

Pushidrosal has the main task of organizing hydrooceanographic guidance which consists of surveys, research, marine mapping, publications, the application of the marine environment, and navigation safety for both the interests of the national army (TNI) and the public interest, in which aims to prepare data and information on defence areas in the sea in supporting the Navy task principles. The tasks and functions of the Pushidrosal are directed in producing marine development products from hydrographic mapping and survey activities that have important and strategic values to support shipping security and safety in all Indonesian waters.

The existence of Pushidrosal as Kotama of the Navy carried out the task of supporting the Indonesian Navy in carrying out Military Operations for War (OMP) and Military Operations Other Than War (OMSP) as mandated by Presidential Regulation No. 62 of 2016 concerning the Organizational Structure of the Indonesian National Army. Moreover, pursuant to Presidential Decree No. 288 of the Republic of Indonesia, the Government of the Republic of Indonesia has named him as the Republic of Indonesia's representative in the World Hydro Graphic Organization (IHO), the East Asia Hydro Graphic Commission (EAHC), and several other foreign professional organizations in the field of hydro graphic.
As an internationally recognized institution, all aspects related to quality improvement should be fulfilled. However, based on the facts in the field there is still a shortage of educators from the best universities in Indonesia. In addition, there is some teaching staff who teaches in the Hydro-Oceanographic Officer Specialization Education Program, in the Navy's HydroOceanographic Education Center that is still multiple positions between academics and bureaucracy so that they do not focus on carrying out their duties.

The condition above makes Pushidrosal have specific and different tasks and functions compared to other unit in national army (satker), as well as in the Indonesian Navy. The logical consequence of the condition is the emergence of demands on the quality power of personnel who are reliable and meet the standards of Hydrographic surveyors because the quality of products produced by preservatives at Pushidrosal will be used for national and international interests.

Achieving Pushidrosal assignments in the future will be faced with a spectrum of increasingly complex task challenges that are transformed in the form of the use of science and technology in the interests of hydrographic and oceanographic mapping surveys demanding professional organization preservatives who have qualifications according to professional fields to guarantee the implementation of tasks organization.

The Navy Chief of reference [5], concerning the Guidance Book for the Implementation of Professional Navy Officer Personnel Development explains that the success of an organization in achieving its objectives is largely determined by various factors, one of which is Human Resources (HR) which is essentially the main driver of organizational dynamics. To create professional human resources, systematic, directed and continuous guidance is needed through education and practice and the provision of assignment experiences that are in accordance with the development of the profession.

According to Gozali in reference [2] that HR development is an activity that must be carried out by the organization in order to train their knowledge, abilities and skills that are in accordance with the demands of the work. Then, it is expected to improve and overcome deficiencies in carrying out work better, in accordance with the development of science and technology used by the organization. Thus, it becomes an effective way to deal with challenges including lagging and diversity of HR.

One way to enhance the professionalism of Pushidrosal workers is to complete assignments and jobs that provide the company with a competitive advantage. The Pusdikhirosal organizes the Hydrographic and Oceanographic Specialization Education (DikspespaHidros) carried out based on the TNI Commander's Regulation number, perpang / 7 / V / 20017 
dated 16 May 2017 concerning approval and ratification of validation, from the Naval Education Command (Kodical) to the Naval Development and Education Command (Kobangdikal) as well as giving the task of organizing Hydro-Oceanographic Education.

Pusdikhidros is in charge of organizing hydrographic and oceanographic education aimed at training and equipping officers in the Indonesian Navy to become SaptaMarga Warriors who are capable of preparing and conducting hydrographic and oceanographic mapping surveys to support military and non-military interests.

\subsection{Specialitazion}

The Educational Objectives of the HydroOceanographic Specialization are to educate and equip Indonesian Navy student officers to become SaptaMarga Warriors who have physical adaptability and professionalism in the sea and are able to plan and carry out hydro-oceanographic mapping surveys to support military and non-military interests [3].

Some concepts regarding the purpose of education / learning objectives include; according to [4], Definition of Learning Goals (i.e. Learning Objectives): "... brief, clear statements that describe the desired learning outcomes of instruction; i.e., the specific knowledge, skills, values and attitudes of students should exhibit that reflect the broader goals. Learning objectives are: brief and clear statements on learning outcomes such as; improvement of students' knowledge, skills, values and attitudes. Learning aims to create continuous changes in the behavior and thinking of students in a learning environment.

While according to [6], it means that self-learning is driven by their learning goals, implementing effective learning strategies, monitoring their progress, establishing conducive to learning environmental conditions, and keeping a sense of self-efficacy for learning. Learners can learn independently, have motivation if supported by learning goals, apply effective learning strategies, monitor student progress, apply conducive environmental conditions for learners. A learning process cannot be separated from teaching and learning activities.

\subsection{Hydro Oceanography}

The existence of qualified and competent human resources (HR) is absolutely necessary because in turn it will have implications for improving the ability of the hydro-oceanography profession. Therefore, strategic steps are needed that must be carried out immediately to overcome the HR problems in the hydro-oceanography profession in Indonesia. So in this knowledge-based era what happens is competition between the level of knowledge and the level of knowledge possessed by the human resources of each country. Regarding human resources, [7] say: These propositions can be included in seven fields of human resources management: culture, style management, employee involvement and influence, remuneration, training and development, recruitment and selection , and job security / lay-offs. There are several parts of human resources including; organizational culture, management style, involvement or influence, remuneration, training or development, recruitment / selection and job security. With the availability of quality human resources by mastering science and technology this greatly determines the ability of the nation to enter global competition that demands high competitiveness.

In line with the statement reference [8], say that HRM involves some activities such as orientation, socialization, training, and development, as well as performance appraisals, which would increase the tacit knowledge (e.g., organizational missions, goals, culture, specific jobs) as well as increasing and general business and industry knowledge. Therefore, recruiting and choosing activities such as orientation, socialization, training, and growth, as well as performance appraisals that contribute to improved awareness of participants, become the method in human resource planning.

Reference [8] was defined that HRM program activities and curricula development should be focused on instilling, improving, and evaluating knowledge, skills, and abilities. Curriculum development is one type of program for developing human capital that focuses on planting, growing awareness, improving skills, and reviewing different policy programs. Furthermore, according to reference [9], human resources (HR) roles, leaders, and HR play an important role in many organizations. Specifically, the HR role has the potency to incorporate the specific practices that enhance employees' expectations of and commitment to change. It works and plays a critical role in organizational change. In particular, the function of human resources has the ability to implement specific practices that increase commitment to change.

Based on a number of definitions above, it can be concluded that human resources become the productive individuals who work as an activator of an organization, whether in an institution that has a function as an asset so it must be trained and developed its capabilities.

\section{METHODS}

The method used in this study was a program or policy evaluation research method. According to reference [10], there are some aspects that should be concerned in evaluation research method. They cover in reaction, learning, behavior and result. The source of main data was obtained from program alumni informant such as Work Unit Heads, Pusdikhidros Staff Officers, Teaching Operations Officers. SepaHidros, Head of 
Education Operations Sub Division Pusdikhidros and Head of Education Assessment Sub-Section Pusdikhidros, Head of Section or Ka Unit Survey that handles jobs in the field of Hydrographic, Oceanographic, and Mapping as 4 direct supervisors, Head of Hydrographic Affairs, Oceanography, and Mapping in each Unit as coworkers.

In addition, the researched used some techniques in collecting data through observation, interview and document analysis. It was used to get as much information as possible about the Evaluation of the Specialist Hydro-Oceanographic Officer Program in the Indonesian Navy's Hydro-Oceanographic Education Center.

\section{RESULTS AND DISCUSSION}

\subsection{Level Reaction}

Curriculum, material, teaching methods, teaching personnel, education staff, facilities and infrastructure, and budget are all included in the assessment level reaction, as seen below;

Curriculum aspects, DikspespaHidros Study Program with the qualifications of the Navy's Hydrographic Surveyor Professional Specialization use the education curriculum set by the Navy (Kasal Decree Number Kep / 595 / IV / 2015 dated April 7, 2015) compiled based on the International Federation's Surveyor Hydrographic education curriculum from the International Federation of Surveyors / The Fédération Internationale des Géomètres (FIG), the International Hydrographic Bureau (IHB) and the International Hydrographic Organization (IHO) or better known as the Standards of Competence for Hydrographic Surveyors, S-5 "eleventh edition of 2010 (Enhancements from M- 5).

The DikspespaHidros Program as a program of the National Hydrospecific Field which refers to the IHO Curriculum has been recognized as the Basic Hydrographic Course by the International Hydrographic Organization (IHO), Federation Internationale des Geometrics (FIG), and The International Cartographic Association (ICA) or IHO-FIG-ICA, especially in the implementation of the "B" Hydrographic Surveyor Category for Navy Officers in the field of expertise (specialization) "Nautical Charting Hydrography and Coastal Zone Management (Specialization in Hydrographic and Hydrographic Sea mapping) Coastal Area Management). It can be demonstrated by obtaining the 4th Recognition / IHO Accreditation Certificate dated April 25, 2013.

The HydrosDikspespa curriculum material focused on the basic material of the Hydrographic Surveyor in the form of exact lessons that required strong personnel skills in Mathematics, Physics, Electronics, Computer Programming, Hydrography, and Oceanography, where the given subjects are high. The skills become a must for DikspespaHidros participants because the lesson hours are so limited; in other words, Officers Students must be able to grasp the subject matter in a short amount of time.

The aspect of the teaching method which was applied at Pusdikhidros was theoretical learning in the classroom, in the form of lectures, discussions and completing the tasks of the teaching staff. Guided practice lessons in the field, in the form of the practice of using equipment carried out at the hour after class in the classroom, were conducted in the afternoon and guided by educators. Then, Independent field practice in conducting a HydroOceanographic survey in the field independently started from planning, implementing and preparing reports and field painting sheets.

Most aspects of teaching staff, who had been teaching in DikspespaHidrosprodik, were still mostly from Pusdikhidros. It was only as much as $50 \%$, while from Pushidros was as much as $40 \%$ and from outside the Navy (ITB and BPPT) as much as $10 \%$. Hence, the additional educators from the best universities in Indonesia were related to programs to develop and to maximize the quality of education.

Educators were another critical factor in the DikspespaHidros practice's implementation. Since all educators came from the Indonesian Navy's Pusdikhidros, the Indonesian Navy's Pusdikhidros, and retired Indonesian Navy, almost all educators who help the DikspespaHidros practice activities appeared well and were ready to assist students in the region. General educators, who had worked in the area of DikspespaHidros operations, had hydrographic skills which were accordance with educational backgrounds such as bachelor, master and doctoral program.

In education aspect, Pusdikhidros was an international national school that promoted high human quality and mastery of science, mental maturity, freedom of creativity and upholds the formation of noble attitudes, so that it required education personnel who were able to support the administrative needs of students and help students improve their quality. The current education staff at Pusdikhidros was in $76 \%$ based on the 2012 DSP (List of Personnel Arrangements)

There were four aspects of facilities and infrastructure that were assessed: quality of equipment, quantity of equipment, comfort of location, and completeness of location. The completeness of the site received the highest average value, while the efficiency of the facilities received the lowest average value. The evaluation results of the participants' reactions to the facilities and infrastructure showed that it could be said that the alumni were satisfied with the teaching staff who supported the DikspespaHidros practice activities.

The decision on the evaluation of facilities and infrastructure components was strengthened by the 
results of interviews with alumni and PaopsjarSepaHidros. PaopsjarSepaHidros stated that the determination of the practice area was based on the ease of mobilization due to the limitations of some equipment owned by Pusdikhidros. The current location of the HidrosDikspespa in the Jakarta Bay of Taman Impian Jaya Ancol waters was able to accommodate practical material. Alumnus stated that the location for implementing the DikspespaHidros practice was not a problem, but the location selection was focused on accommodating all practical material.

Budget aspect, according to the plan for the needs of the DikspespaHidros based on the TA's education plan budget at that time TA. 2012 S. TA. In 2014 the submission was fully supported by Kodikopsla / Kobangdikal. Starting in the 2012 Budget Year (Pusdikhidros) has educated foreign / foreign students from Asia at the level of 11 officers.

\subsection{Learning Stage}

Learning, at the assessment stage, consists of growing awareness, skills, and attitudes, as outlined below:

Aspects of increasing knowledge, academic assessment included aspects of knowledge and skills obtained through theoretical lessons, practical lessons and practice. Educational Achievement Values, or the value earned by students according to the graduation level that must be equal to or higher than the minimum passing grade cap that were used to assess graduation for students.

Written tests were used in subjects of more than 10 samples of lessons. Written exams administered one week after the subject had been completed or the necessary number of lesson hours have been completed. Subjects with less than 10 samples lessons were assessed by the use of tasks, questions, and resumes.

Aspects of ability improvement, evaluation carried out by good practice examined during the classroom learning process and during the HidrosDikspespa Practice implementation. The practice exam during the learning process was carried out by each educator to determine the ability of students in terms of using equipment and theory, accuracy and precision in data collection in processing and presenting data. The practical examination during the implementation of the DikspespaHidros practice was conducted through the assignment of tasks both individually and in groups according to the planned practice material.

Aspects of attitude, the assessment was carried out since the opening of the DikspespaHidros until the end of education. The assessment was carried out directly by Pabingsis and Bingsis. Assessment of attitudes included mental spiritual, ideological, soldiering and leadership attitudes. The method of adding and subtracting values was used in assessment. A value of 81 was allocated to all students at the start of their education. If students demonstrated achievement, this value will rise; however, if students commit violations, this value will fall.

\subsection{Behavior Stage}

At the behavior stage, it consisted of work ability and work motivation which can be summarized as follows:

The workability aspect was divided into 3 components, namely cognitive ability, physical ability, and emotional ability. The cognitive abilities of the alumnus applied knowledge well into the work, the alumni's physical abilities in carrying out the tasks in good work and the emotional abilities of the alumnus were able to show good working attitudes.

Aspects of work motivation can be seen through several components such as discipline which meant that the accuracy of alumni finished with good work. In addition, alumni responsibility meant the responsibility of alumni in carrying out good duties. Also, confident alumnus meant that alumni confidence in doing work according to SOP was quite good. Besides, initiative meant the ability of alumni to find opportunities and finding ideas in completing good work. Furthermore, loyalty meant the ability of alumni to obey the rules and standards of good work.

\subsection{Result Stage}

The result level of the assessment was efficiency and productivity which can be summarized as follows;

Individual performance dimensions, as well as alumni covering aspects of work quality, quantity, teamwork, and work participation, are all rated as strong. Graduates of the DikspespaHidros, especially those who served at the Pusdikhidrosal, can generally participate directly in the Dikspespa Operation Hidros. Non-hydros alumni (Armada, Lantamal, and Lanal) also needed assistance in looking for jobs. In terms of successful alumni in general, sufficient work programs, sufficient work plans, good responsibility, sufficient work precision, sufficient tool use values, good work concentration, and sufficient work procedures were needed. Non-hydros DikspespaHidros graduates, on the other hand, were very capable of carrying out their duties, but they still need guidance because when they were assigned as a learning process.

In terms of workplace efficiency, the DikspespaHidros alumnus had generally been able to perform the job in the HidrosDikspespa Operation. Graduates who had worked at Pusdikhidros would have a greater understanding of work than non-hydros alumni. Graduates of the Pusdikhidrossatker program usually have DikspespaHidros operational experience but lack the legality of commingling. Non-Hidros alumni generally understood sufficient work methods and work 
procedures. However, the use of equipment still needed to be done intensively because the development of the science and technology field of DikspespaHidros continued to the progress.

\section{CONCLUSIONS}

Based on the findings and discussion of the evaluation of the hydro-oceanographic officer specialization education program, at the center of the Navy's hydro-oceanographic education, there are several recommendations that need to be conveyed in an effort to improve and develop the program. The following recommendations from researchers include;

\subsection{Reaction}

a. It is important to involve educators from the best universities in Indonesia in the development of programs to improve education quality.

b. Educators who teach in the Hydro-Oceanographic Specialization Education Program, at the Center for Hydro-Oceanographic Education of the Indonesian Navy only focus on teaching, but they do not duplicate the academics and bureaucracy.

c. It is necessary to have human resources who have certification as educators.

d. There is a balance between the proportion of material with the orientation of developing skills, knowledge, mentality, and ideology.

e. The budget needs to be raised in order to fulfill the program's requirements.

\subsection{Learning}

It is necessary to make a high standard of assessment on academic graduation, ability skills and attitudes.

\subsection{Behavior}

a. It is required to make technical guidelines or manuals regarding work ability and work motivation.

b. It is expected to be able in applying the values of SaptaMarga in organizational and daily life.

\subsection{Result}

It is necessary to increase in the collaboration between the alumni of the Pusdikhidrossatker and nonHydros alumni so that they are able to carry out some of the HidrosDikspespa Operations work properly.In addition, Performance and productivity need to be increased optimally.

\section{REFERENCES}

[1] Pushidrosal, Organization and procedure hydrographic and oceanographic center, Jakarta, 2016.

[2] M. Kadarisman, Manajemen pengembangan sumber daya manusia, Rajawali Press. Jakarta. 2012.

[3] History and Profile of Pusdikhidros TNI AL, "History and profile of pusdikhidros tni al," no. June, 2011.

[4] M. Zlatović, I. Balaban, and D. Kermek, "Using online assessments to stimulate learning strategies and achievement of learning goals," Comput. Educ., 2015, doi: 10.1016/j.compedu.2015.09.012.

[5] Peraturan Kepala Staf Angkatan Laut Nomor :Perkasal/1/I/2010 tanggal 13 Januari 2010 tentang Buku Petunjuk Pelaksanaan Pembinaan Profesi Personel Perwira TNI Angkatan Laut.

[6] S. Scrimin, E. Patron, E. Ruli, C. E. K. Pagui, G. Altoè, and L. Mason, "Dynamic psychophysiological correlates of a learning from text episode in relation to reading goals," Learn. Instr., 2018, doi 10.1016/j.learninstruc.2018.01.007.

[7] K. Zabalza and J. Matey, "Privatisation and changes in human resource management: Evidence from Spain,” Int. J. Hum. Resour. Manag., 2014, doi: $10.1080 / 09585192.2011 .565664$

[8] P. D. Brewer and K. L. Brewer, "Knowledge management, human resource management, and higher education: a theoretical model," J. Educ. Bus., 2018, doi: 10.1080/08832321003604938.

[9] B. E. Baran, J. N. Filipkowski, and R. A. Stockwell, "Organizational change: perspectives from human resource management," J. Chang. Manag., 2018, doi: 10.1080/14697017.2018.1502800.

[10]R. B. Gunderman, S. Chan, “Kirkpatrick's evaluation of educational programs and its relevance to academic radiology," International J. Academic Radiology, 22, 2015

A. Shahshahani, Mahshid. et. Al, "The evaluation of reproductive health program in iran: a cipp model approach," Procedia - Social and Behavioral Sciences 197, 2015.

[11]A., Erika L, Conducting quantitative medical education research: from design to dissemination, Academic Pediatrics, 2018.

[12] A., H. Soodmand et. al., "On the relationship among iranian esp learners' learning strategy use, learning 
styles and their english language achievement," International J. Procedia - Social and Behavioral Sciences, 192, 2015.

[13]A., Joseph, Evaluating the impacts of global environmental assessments. Environmental Science and Policy, 2017.

[14] A., Lorraine, et. al, "An evaluation of approaches used to teach quality improvement to preregistration health care professionals: an integrative review," International J. of Nursing Studies, 73, 2017.

A. Appannah, et. al, "Diversity training for the community aged care workers: a conceptual framework for evaluation", International J. Evaluation and Program Planning, 2017.

[15]A., Tarek, M. Szanyi, "Designing evaluations: a study examining preferred evaluation designs of educational evaluators," Studies in Educational Evaluation, 2011.

[16]B., Mostafa et. al, "Evaluating the effectiveness of a continuing education program for prevention of occupational exposure to needle stick injuries in nursing staff based on kirkpatrick's model," J. of the National Medical Association, 19,2017.

[17] B, Susan E, C. L. Ayar, "Evaluation of a drug and alcohol safety education program in aviation using interrupted time series and the kirkpatrick framework," Evaluation and Program Planning, 2019.

[18]B. Vera dan U.-Marie Krause, "Instructional methods and languages in class: a comparison of two teaching approaches and two teaching languages in the field of intercultural learning," International J. Learning and Instruction, 2016.

[19]C., Dale et. al, "Assessment of operational effectiveness for education program providers," J. of Assessment and Institutional Effectiveness, 4, 2016.

[20]C., Huey-Tsyh, "Practical program evaluation: assessing and improving planning, implementation, and effectiveness," London United Kingdom: Sage Publications, Inc, 2005.

[21]C., Konstantina, M. Virvou, "PeRSIVA: an empirical evaluation method of a student model of an intelligent e-learning environment for computer programming," International J. Computers \& Education, 68, 2013.

[22] C. Thomas G. Christopher G. Worley, Organization Development \& Change 10 Editions, USA: Cengange Learning, 2015.
[23] C., Mariel, et. al, "Implementation and evaluation of an innovative leadership and teacher training program fornon-physician emergency medicine practitioners in uganda," African J. of Emergency Medicine, 2019.

[24] C., Cynthia M. et. al, "Nursing graduates' ability to address incivility: kirkpatrick's level-3 evaluation,' International J. Clinical Simulation in Nursing, 2014.

[25]C., Liesje et. al, "Understanding individual differences in approaches to learning across courses: a mixed method approach," International J. Learning and Individual Differences, 2016.

[26]D., Sara et. al. The effect of content and language integrated learning on students' english and history competences e killing two birds with one stone? International J. Learning and Instruction, 41, 2016.

[27] 2016, DinasHidro - Oseanografi TNI AL. Rencana Pembangunan KekuatanPusdikhidros TNI AL. [online] Jakarta.

[28]D. P. Slakey, et. al, "Evaluating a surgeon led training program: targeting kidney disease in vietnam,” International J. of Surgery Open, 2016.

[29]A.A. Drozdova, \& A.I. Guseva, "Modern technologies of e-learning and its evaluation of efficiency," International J. Procedia - Social and Behavioral Sciences, 237, 2017.

[30] A.D. Farashah,. "Exploring the value of project management certification in selection and recruiting”. International J. of Project Management 37, 2019.

[31] S. Farjad, "The evaluation effectiveness of training courses in university by kirkpatrick model," Case Study: Islamshahr university, International J. Procedia- Social and Behavioral Sciences, 46, 2012.

[32] 2014, F. Nickols. "Evaluating training there is no cookbook approach, 200. [Online]. Available: htpp://www.home.att.net/-nickols/shifts.htm.

[33] B. Froncek, "Evaluator competencies in the context of diversity training: the practitioners' point of view" Evaluation and Program Planning, 67, 2018.

[34] S. Goodier, et. al, "The need for theory evaluation in global citizenship programmes: the case of the gcsaprogramme," Evaluation and Program Planning, 66, 2017.

[35] K. Hakan, F. Sevalb, CIPP evaluation model scale: development, reliability and validity, Procedia Social and Behavioral Sciences, 2011.

[36] J. Hanaysha, Examining the effects of employee empowerment, teamwork, and employee training 
on organizational commitment," International J. Procedia - Social and Behavioral Sciences, 229, 2016.

A. Hasan, et. al, "A conceptual framework for mechatronics curriculum using stufflebeam cipp evaluation model," International J. Procedia-Social and Behavioral Sciences, 195, 2015.

[37]H. Lin, Chin, Y. Zhang, B. Zheng, "The roles of learning strategies and motivation in online language learning: a structural equation modeling analysis," International J. Computers \& Education, 2017.

[38] G.-J. Hwang, dan S.-Yi Wang, "Single loop or double loop learning: english vocabulary learning performance and behavior of students in situated computer games with different guiding strategies," International J. Computers \& Education, 102, 2016.

[39] M. Jamalzadeh, Z. Shahsavar, "The effects of contextual factors on teacher's beliefs and practices," International J. Procedia-Social and Behavioral Sciences, 2015.

[40]L. Tainioa Karvonena, Ulla, S. Routarinne, "Uncovering the pedagogical potential of texts: curriculum materials in classroom interaction in first language and literature, education, learning," International J. Culture and Social Interaction, 2017.

[41] Kaswan, Pelatihan dan PengembanganUntukMeningkatkanKinerja SDM, Bandung : Alfabeta, 2011.

[42] M. Lippe, P. Carter, "Using the cipp model to assess nursing education program quality and merit," Teaching and Learning in Nursing, 2018.

[43] R. N. Mahdi, et. al, "A critical review of recent trends in second language syllabus design and curriculum development," International J. of Research Studies in Language Learning, 2013.

[44] S. Makumbe, "Effectiveness of using learning factories to impart lean principles in mining employees," Procedia Manufacturin, 2018.

[45] M. N. Mamaril, et. al, "Weaving evaluation into the waipa ecosystem: placing evaluation in an indigenous place-based educational program," Studies in Educational Evaluation, 56, 2017.

[46] K. Maria, "Evaluation tool for the forcastinginitial evaluation of school environmental projects: a case study," International J. of Advanced Research, 5, 2016.

[47]H. Woodland, Mazur, Rebecca, Rebecca, "evaluation of a cross-cultural training program for pakistani educators: lessons learned and implications for program planning," J. International Evaluation and Program Planning, 2017.

[48] C. James, McDavid, dan Hawthorn, Laura R.L, Programme evaluation \& performance measurement: an introduction to practice, California: Sage Publication, 2006.

[49] P. Mellor, et. al. "A critical review of transition to professional practice programs: applying a standard model of evaluation," J.of Nursing Regulation, 8, 2017.

[50] J. M. Miles, S. S. Elaine, "A new leadership development model for nursing education," J. of Professional Nursing, 2018.

[51] S. Abolfazl, Miri, et. al, "Staff organization training: designing, stages, and methods," International J. Procedia - Social and Behavioral Sciences, 129, 2014.

[52]L. Moldovan, "Training outcome evaluation model," International J. Procedia Technology, 22, 2016.

[53]C. Moreira, et. al, 'Learner's perception, knowledge and behavior assessment within a breastimaging e-learning course for radiographers,' European J. of Radiology, 2019.

A. Robson, D. Sloan, Neumann, Jan, "Monitoring and evaluation of strategic change programme implementation," International J. Evaluation and Program Planning, 66, 2017.

[54]M. Arab Neyazi, Arges, "Evaluation of selected faculties at tehran university of medical sciences using cipp model in students and graduates point of view," Evaluation and Program Planning, 59, 2016

[55] W. Null, Curriculum from theory to practice, Lanham: Rowman \& Littlefield Publishers, 2011.

[56] P. Laihonen, Tamas dan P. Szabo, "Studying the visual and material dimensions of education and learning" International J. Linguistics and Education, 2017.

[57] J. C. Pradarelli, et. al, "A leadership development program for surgeons: first-year participant evaluation, "International J. Elsevier, 2016.

[58]Riduwan. Skala pengukuranvariabel-variabel penelitian," Bandung: Alfabeta, 2012.

[59]D. Royse, et. al, Program evaluation: an introduction, 5th Edition. New York: Cengange Learning,2010.

[60]L. Rooshenas, et. al, "The quintet recruitment intervention supported five randomized trials to 
recruit to target: a mixed-methods evaluation," J. of Clinical Epidemiology, 2018.

[61]S. F. Shawer, "Teacher-driven curriculum development at the classroom level: implications for curriculum, pedagogy and teacher training," International J. Teaching and Teacher Education, 63, 2017.

[62] S. Silaen, dan Widiyono, Metodologi penelitian sosial untuk penulisan skripsi dan tesis, Jakarta: In Media, 2013.

[63] N. A. Soliman, "Teaching english for academic purposes via the flipped learning approach," International J. Procedia-Social and Behavioral Sciences, 232, 2016.

[64]D. L. Stufflebeam dan J. S. Anthony, Evaluation theory, models, and applications. San Francisco: Jossey-Bass, 2007.

[65] E. Sucuoglu, "Analysis of motivational strategies used by english language teachers teaching at secondary schools," International J. Procedia Computer Science, 120, 2017.

[66] L. J. Sundean, et. al, "Governance education for nurses: preparing nurses for the future," J. of Professional Nursing, 2018.

[67]C. A. Surr, "Gates what works in delivering dementia education or training to hospital staff? acritical synthesis of the evidence. International J. of Nursing Studies, 2017.

[68] M. Tangaa dan M. Cosmas, "Exploring the recruitment and training of peer facilitators in a south african university," International J. of Educational Development, 2018.

[69] S. Lancaster, Topper, Andrew "Online graduate educational technology program: an illuminative evaluation, Studies in Educational Evaluation, 51, 2016.

[70] O. Vavelyuka, "To integrate successfully: language and subject studies in esp teaching," International J. Procedia-Social and Behavioral Sciences, 2015.

[71]C. Vos, Vuurberg, "The effectiveness of interprofessional classroom-based education in medicalcurricula: a systematic review," J. of Interprofessional Education \& Practice, 2018.

[72] Yi, Lu, et. al, "Conceptual modeling of training and organizational risk dynamics," International J. Procedia Engineering, 80, 2014.

[73] T. Yongliang, "Evaluation of simulation-based training for aircraftcarrier marshalling with learning cubic and kirkpatrick's models. Chinese J. of Aeronautics, 2015.
[74]Zhao, Ying, et. al, A pilot study on the simulationbased training for ethiopia skilled birth attendants, Nurse Education in Practice, 2019.

[75]D. S. Zhu, Yan, "Implementing foreign language curriculum innovation in a chinese secondary school: an ethnographic study on teacher cognition and classroom practices," International J. System, 2017.

[76] Peraturan Kasal Nomor: Perkasal/47/VI/2009 Tanggal 19 Juni 2009 Tentang Petunjuk Pelaksanaan Evaluasi di Lembaga Pendidikan TNI AL.

[77] Tentara Nasional Angkatan Laut. (2009). Peraturan Kepala Staf Angkatan Laut Nomor : Perkasal/47/VI/2009 tentang Petunjuk Pelaksanaan Evaluasi di Lembaga Pendidikan TNI AngkatanLaut. 